\title{
How is technology changing the World landscape? A view over the European continent.
}

\author{
Catalin Vrabie ${ }^{1}$ and Andreea-Maria Tirziu ${ }^{2}$
}

\begin{abstract}
We are used to look at geographical, economic, political or even religious maps of our planet. Cybernetics, which is a relatively new science that forcedly makes its way through already existing sciences, it is creating its own map. Obviously, despite the young age, its complexity does not permit detailing of each component. This article focuses on the digital divide on the European continent. Starting from an analysis on local communities in Romania from 2010 up till now, the intention to extend the study to the entire region and then to the whole continent did not take long to appear, but unfortunately the complexity and lack of resources are proving to be a great barrier. In spite of this, we analysed at a national level (using a series of criteria proposed by the ECDL Foundation, together with those proposed by UNESCO and adapted according to the literature studied) all European countries, which possess as we know, important similarities and differences related to their political, social, and economic contexts. As a result, we created a map of the level of information technology's adoption amongst population. The research question this study investigates is how contextual features serve to influence the adoption of technology among different countries in Europe - focusing in particular at Romania. Due to the fact that high dispersion of results for indicators within the same country raises many questions, we conclude saying that the success of IT\&C projects is to a large extent contingent upon political and economic contexts, while being less related to social contexts. The article also wants to be a scientific debates initiator, whose purpose is to present, in a formal framework: university courses, conferences, seminars, solutions and strategies of increasing the value of the indicators in question.
\end{abstract}

\section{Introduction}

Nowadays, the globalization and economic competition should make governments to prioritize education - in all of its aspects: quality, equal opportunities for everybody and lifelong learning. Experts and policymakers are agreeing on the fact that Information and Communication Technology (ICT) helps people around the world to compete, despite the geographical borders, by adding new skills to each learner. Moreover, they emphasize the fact that ICT is a multiplier factor for both educators and learners. On one hand, the educators will decrease their expenditure associated with traditional instruction and they improve themselves by an easy access to other trainings and, on the other hand, the learners get new skills and they might get in contact with teachers virtually even if they are living in rural areas.

Beyond all that, there are few questions on the issue of the usage of Information Technology, most of them related to the learning achievements as well as to the ease of retention. Some researchers believe that computers might change the teaching and learning environment [1], [2], [3], while others are saying that all that matters is the pedagogy and the ICT is only providing a way to deliver

\footnotetext{
${ }^{1}$ Lecturer, PhD. The National University of Political Studies and Public Administration (SNSPA) - Faculty of Public Administration, Bucharest, Romania. Email: cataloi@yahoo.com

$2 \mathrm{PhD}$ Candidate, The National University of Political Studies and Public Administration - Faculty of Public Administration, Bucharest, Romania. Email: tirziu.andreea@yahoo.com
} 
the information from teachers to learners [4]. However, the impact of ICT in education is clear and by that we emphasise the importance of integrating it all-over Europe.

\section{ICT in education}

Education experts, along with policymakers, are trying for decades to include ICT on the educational reforms around Europe - both at the national level as well as for the entire EU. At the European level, Council of European Professional Informatics Societies (CEPIS) is drawing policies for integrating ICT everywhere, including education. Having as a goal "to promote the development of the Information Society through digital literacy, skills, education \& research and professionalism" [5] CEPIS task force creates in 1995 the European Computer Driving Licence (ECDL) concept, supported by the European Commission through the ESPRIT research programme, "to examine how to raise the levels of digital literacy throughout Europe" [6]. Moreover, by its mission, it is undoubtable that ICT is seen as a way to eliminate exclusion and to improve the quality of life.

Even though we assist to this growing demand for information technology in the educational sector, most of the statistics lack basic information about the policies [7]. The European Commission is not providing proper indicators to measure the inputs and outputs from ICT investments in education however, datasets regarding students and their performance (regarding ICT) are available.

Unfortunately, to the authors' knowledge, the data available are focused on pupils, students and other learners that are enrolled in the educational system; but there are others, that are not. According to Eurostat "digital divide refers to the distinction between those who have Internet access and are able to make use of new services offered on the World Wide Web, and those who are excluded from these services." [8]. Therefore, beyond the available statistics, there are other categories of people who are not in contact with technology.

\section{Methodology}

Digital divide might be measured by technical indicators, as some researchers are doing it: Mobile cellular telephone subscriptions, Internet users, Fixed telephone lines, Mobile broadband subscriptions, Fixed broadband subscriptions and so on [9], but we assume that beyond the digital divide there are strong financial factors that should be taken into consideration as well as social factors and education policies - how much money the government invest in education, for example. Of course, ample research has already investigated the extent to which certain factors are influencing the digital divide (like GDP-ICT penetration relationships or even education and ICT use); however, to the authors' knowledge little research has attempted to understand what conditions should be present for reducing it.

The most significant obstacle in collecting the data was the huge variety of sources - not all of them providing the same figures. Although, the differences were not significant, we took into consideration the sources mentioned below because they clearly provide the most accurate and up to date figures by being well known international organisations and by that, we assume they are trustable.

Therefore, in this article we looked over statistics made on all twenty-eight European countries by UNESCO Institute for Statistics, Council of European Professional Informatics Societies (CEPIS), Internet World Stats, EMEA Satellite Operators Association (ESOA) by their program Broadband 
for all and European Commission by the Digital Single Market and Digital Agenda scoreboards. The intention is to explore the relationships between economic and social context and the ICT penetration, considering this as being factors that influence the adoption of technology among different countries in Europe [10], [11] - paying a special attention to the Romanian case.

Firstly we looked at the GDP - to have an overall image over the countries, and GDP per capita to better understand the differences among them and then, we had a look at the state investments in the field of education (as percentage of GDP) and in Research and Development (GERD - Gross domestic expenditure on R\&D) in the area of Engineering \& Technology.

Secondly, but very important in terms of comparison, we looked for the number of Internet users as percentage of population and if they access the global network by a high-speed connection (Broadband).

At the end we draw maps of Europe, highlighting the differences we found, trying to see if, by overlapping them, there are any correlations among the indicators. We must add here that all of the European nations possess important similarities and, of course, differences related to their political, social, and economic contexts. In addition, little to none of the European nations possesses a similar timeline with regard to the evolutions of their democracies, which makes comparisons of ICT use in each of them particularly interesting.

\section{Results}

The existence of data, collected systematically by different organisations, helps researchers to find correlations among them. However, the figures must be understood in the local / national context. In many countries the integration of ICT is not the main priority of the local government compared to other objectives, including infrastructure investment - Romania and Bulgaria is lacking on highway infrastructure for example [12], or ensuring an adequate number of doctors per thousand inhabitants and so on [13].

In the table below, we present the figures we found by searching the open data bases from the organisations we had in focus for this article. 


\begin{tabular}{|c|c|c|c|c|c|c|c|c|c|}
\hline & $\begin{array}{c}\text { Country } \\
\text { (year of entry) }\end{array}$ & $\begin{array}{l}\text { GDP in } \\
\text { billions } \\
\text { - PPP\$ }\end{array}$ & $\begin{array}{l}\text { GDP } \\
\text { per } \\
\text { capita - } \\
\text { PPPS }\end{array}$ & $\begin{array}{l}\text { Government } \\
\text { expenditure } \\
\text { on education } \\
\text { as } \% \text { of GDP }\end{array}$ & $\begin{array}{l}\text { GERD } \\
\text { as a } \% \\
\text { of GDP }\end{array}$ & $\begin{array}{c}\text { GERD - } \\
\text { Engineering } \\
\& \\
\text { Technology }\end{array}$ & \begin{tabular}{|l|} 
Internet \\
Users \% \\
Population
\end{tabular} & $\begin{array}{c}\text { Broadband } \\
\% \text { Internet } \\
\text { Users }\end{array}$ & $\begin{array}{l}\text { Digital } \\
\text { Skills } \\
\text { (Basic) }\end{array}$ \\
\hline 1 & Austria (1995) & 412 & 47,824 & $5.56 \%$ & $2.98 \%$ & NA & $83.10 \%$ & $99.00 \%$ & $73.90 \%$ \\
\hline 2 & Belgium (1958) & 496 & 43,992 & $6.38 \%$ & $2.46 \%$ & NA & $85.00 \%$ & $100.00 \%$ & $66.00 \%$ \\
\hline 3 & Bulgaria (2007) & 126 & 17,512 & $4.07 \%$ & $0.79 \%$ & $23.70 \%$ & $56.70 \%$ & $90.00 \%$ & $54.80 \%$ \\
\hline 4 & Croatia (2013) & 92 & 21,880 & $4.59 \%$ & $0.81 \%$ & $41.13 \%$ & $75.00 \%$ & $94.00 \%$ & $52.60 \%$ \\
\hline 5 & Cyprus (2004) & 26 & 30,734 & $6.44 \%$ & $0.40 \%$ & $25.44 \%$ & $95.00 \%$ & $100.00 \%$ & $55.10 \%$ \\
\hline 6 & $\begin{array}{l}\text { Czech } \\
\text { Republic (2004) }\end{array}$ & 339 & 32,167 & $4.11 \%$ & $1.99 \%$ & $50.17 \%$ & $79.70 \%$ & $98.00 \%$ & $66.20 \%$ \\
\hline 7 & Denmark (1973) & 265 & 46,635 & $8.61 \%$ & $3.08 \%$ & $4.63 \%$ & $96.00 \%$ & $98.00 \%$ & $58.40 \%$ \\
\hline 8 & Estonia (2004) & 37 & 28,095 & $4.82 \%$ & $1.43 \%$ & $9.12 \%$ & $84.20 \%$ & $88.00 \%$ & $72.90 \%$ \\
\hline 9 & Finland (1995) & 223 & 40,601 & $7.16 \%$ & $3.17 \%$ & NA & $93.50 \%$ & $93.00 \%$ & $72.50 \%$ \\
\hline 10 & France (1958) & 2,651 & 39,678 & $5.51 \%$ & $2.25 \%$ & NA & $83.80 \%$ & $99.00 \%$ & $72.10 \%$ \\
\hline 11 & Germany (1958) & 3,848 & 47,268 & $4.94 \%$ & $2.86 \%$ & NA & $88.40 \%$ & $97.00 \%$ & $74.80 \%$ \\
\hline 12 & Greece (1981) & 289 & 26,680 & NA & $0.83 \%$ & $39.88 \%$ & $63.20 \%$ & $99.00 \%$ & $63.50 \%$ \\
\hline 13 & Hungary (2004) & 252 & 25,582 & $4.23 \%$ & $1.37 \%$ & $53.89 \%$ & $76.10 \%$ & $92.00 \%$ & $61.30 \%$ \\
\hline 14 & Ireland (1973) & 254 & 54,654 & $5.34 \%$ & $1.51 \%$ & NA & $82.50 \%$ & $97.00 \%$ & $59.70 \%$ \\
\hline 15 & Italy (1958) & 2,183 & 35,896 & $4.17 \%$ & $1.28 \%$ & NA & $62.00 \%$ & $98.00 \%$ & $70.90 \%$ \\
\hline 16 & Latvia (2004) & 48 & 24,286 & $4.91 \%$ & $0.69 \%$ & $34.00 \%$ & $82.00 \%$ & $83.00 \%$ & $62.50 \%$ \\
\hline 17 & Lithuania (2004) & 81 & 27,730 & $4.61 \%$ & $1.01 \%$ & $15.15 \%$ & $82.10 \%$ & $97.00 \%$ & $62.10 \%$ \\
\hline 18 & Luxembourg (1958) & 58 & 101,926 & $4.14 \%$ & $1.20 \%$ & NA & $94.70 \%$ & $100.00 \%$ & $79.50 \%$ \\
\hline 19 & Malta (2004) & 13 & 29,526 & $8.29 \%$ & $0.84 \%$ & $29.56 \%$ & $73.20 \%$ & $100.00 \%$ & $65.70 \%$ \\
\hline 20 & Netherlands (1958) & 821 & 48,459 & $5.61 \%$ & $1.90 \%$ & $41.47 \%$ & $95.50 \%$ & $100.00 \%$ & $69.50 \%$ \\
\hline 21 & Poland (2004) & 993 & 26,135 & $4.94 \%$ & $0.90 \%$ & $52.88 \%$ & $67.50 \%$ & $69.00 \%$ & $65.00 \%$ \\
\hline 22 & Portugal (1986) & 302 & 29,214 & $5.28 \%$ & $1.20 \%$ & $41.56 \%$ & $67.60 \%$ & $100.00 \%$ & $65.90 \%$ \\
\hline 23 & Romania (2007) & 424 & 21,403 & $2.95 \%$ & $0.38 \%$ & $42.25 \%$ & $56.30 \%$ & $87.00 \%$ & $35.60 \%$ \\
\hline 24 & Slovakia (2004) & 157 & 28,877 & $4.11 \%$ & $0.88 \%$ & $48.76 \%$ & $83.10 \%$ & $75.00 \%$ & $67.70 \%$ \\
\hline 25 & Slovenia (2004) & 64 & 31,122 & $5.49 \%$ & $2.38 \%$ & $53.66 \%$ & $72.80 \%$ & $74.00 \%$ & $66.70 \%$ \\
\hline 26 & Spain (1986) & 1,603 & 34,527 & $4.30 \%$ & $1.23 \%$ & NA & $76.90 \%$ & $98.00 \%$ & $65.90 \%$ \\
\hline 27 & Sweden (1995) & 455 & 46,420 & $7.72 \%$ & $3.10 \%$ & NA & $94.60 \%$ & $99.00 \%$ & $64.30 \%$ \\
\hline 28 & $\begin{array}{l}\text { United } \\
\text { Kingdom (1973) }\end{array}$ & 2,692 & 41,325 & $5.75 \%$ & $1.70 \%$ & $5.23 \%$ & $91.60 \%$ & $100.00 \%$ & $72.10 \%$ \\
\hline
\end{tabular}

Table 1: A view over the European countries regarding the GDP per capita and the number of Internet users Source: UNESCO Institute for Statistics, Internet World Stats and ESOA, European Commission (2016 figures)

As we can see, regarding the GDP per capita (in PPP\$ - Purchasing Power Parity, as we found it on UNESCO Institute for Statistics) - we have to mention here that we used for this study the latest of the statistics provided by each organisation (2016) the values for the European countries are widely spread, starting from the highest level - Luxembourg with 101.926 PPP\$ per capita, all the way down to Bulgaria with a GDP per capita approximately six times lower (17.512 PPP\$). Furthermore, even thought is not our main focus for this article, we were looking at the correlation between the number of years since a specific country is a European Union member and the GDP per capita. We found that the correlation is positive and very strong (Pearson correlation coefficient, $r$, being 0.651). We see this as a very important contextual factor that contributes to the success or failure of the digital divide policies among European countries. 
According to the table below (Table 2.), beside the correlations we have mentioned above, between the number of years since the European countries acceded EU and GDP per capita $(r=0.651)$ the next strongest correlation is between GDP per capita and the number of Internet users - being $\mathrm{r}=$ 0.584. If we take into consideration that the Educational expenditure is correlated with the number of Internet users by $\mathrm{r}=0.530$, we might think that the policymakers should pay attention more on the education (especially on the field of ICT) in order to contribute to the social category of factors. This statement is strengthened by the very weak correlation between the Internet users and the Digital skills indicator which: $r=0.064$.

What the above discussion suggests is that for the social factors to contribute to the success of digital divide policies, other factors should be take into consideration as well - such as contextual factors.

\begin{tabular}{|c|c|c|c|c|c|c|c|c|c|}
\hline & & $\begin{array}{c}\text { Years in } \\
\text { EU }\end{array}$ & $\begin{array}{l}\text { GDP per } \\
\text { capita }\end{array}$ & $\begin{array}{c}\text { Education } \\
\text { expenditure }\end{array}$ & $\begin{array}{c}\text { GERD } \\
\text { from GDP }\end{array}$ & $\begin{array}{c}\text { GERD in } \\
E \text { and } T\end{array}$ & $\begin{array}{c}\text { Internet } \\
\text { users }\end{array}$ & Broadband & $\begin{array}{l}\text { Digital } \\
\text { skills }\end{array}$ \\
\hline Years in EU & $r=$ & 1 & $.651(* *)$ & .135 & $.390(*)$ & -.287 & .330 & $.507(* *)$ & -.099 \\
\hline $\begin{array}{l}\text { GDP per } \\
\text { capita }\end{array}$ & $r=$ & $.651(* *)$ & 1 & .158 & $.386\left(^{*}\right)$ & -.317 & $.584(* *)$ & $.387(*)$ & -.186 \\
\hline $\begin{array}{l}\text { Education } \\
\text { expenditure }\end{array}$ & $r=$ & .135 & .158 & 1 & $.527(* *)$ & -.449 & $.530(* *)$ & .311 & .076 \\
\hline $\begin{array}{l}\text { GERD from } \\
\text { GDP }\end{array}$ & $r=$ & $.390(*)$ & $.386(*)$ & $.527(* *)$ & 1 & -.180 & $.535(* *)$ & .236 & -.052 \\
\hline $\begin{array}{l}\text { GERD in } \mathrm{E} \\
\text { and } \mathrm{T}\end{array}$ & $r=$ & -.287 & -.317 & -.449 & -.180 & 1 & -.432 & -.451 & -.279 \\
\hline $\begin{array}{l}\text { Internet } \\
\text { users }\end{array}$ & $\mathrm{r}=$ & .330 & $.584(* *)$ & $.530(* *)$ & $.535(* *)$ & -.432 & 1 & .323 & .064 \\
\hline Broadband & $r=$ & $.507(* *)$ & $.387(*)$ & .311 & .236 & -.451 & .323 & 1 & .278 \\
\hline Digital skills & $r=$ & -.099 & -.186 & .076 & -.052 & -.279 & .064 & .278 & 1 \\
\hline
\end{tabular}

Table 2: Correlation between the data sets indicators presented in Table 1

** Correlation is significant at the 0.01 level (2-tailed).

* Correlation is significant at the 0.05 level (2-tailed). 


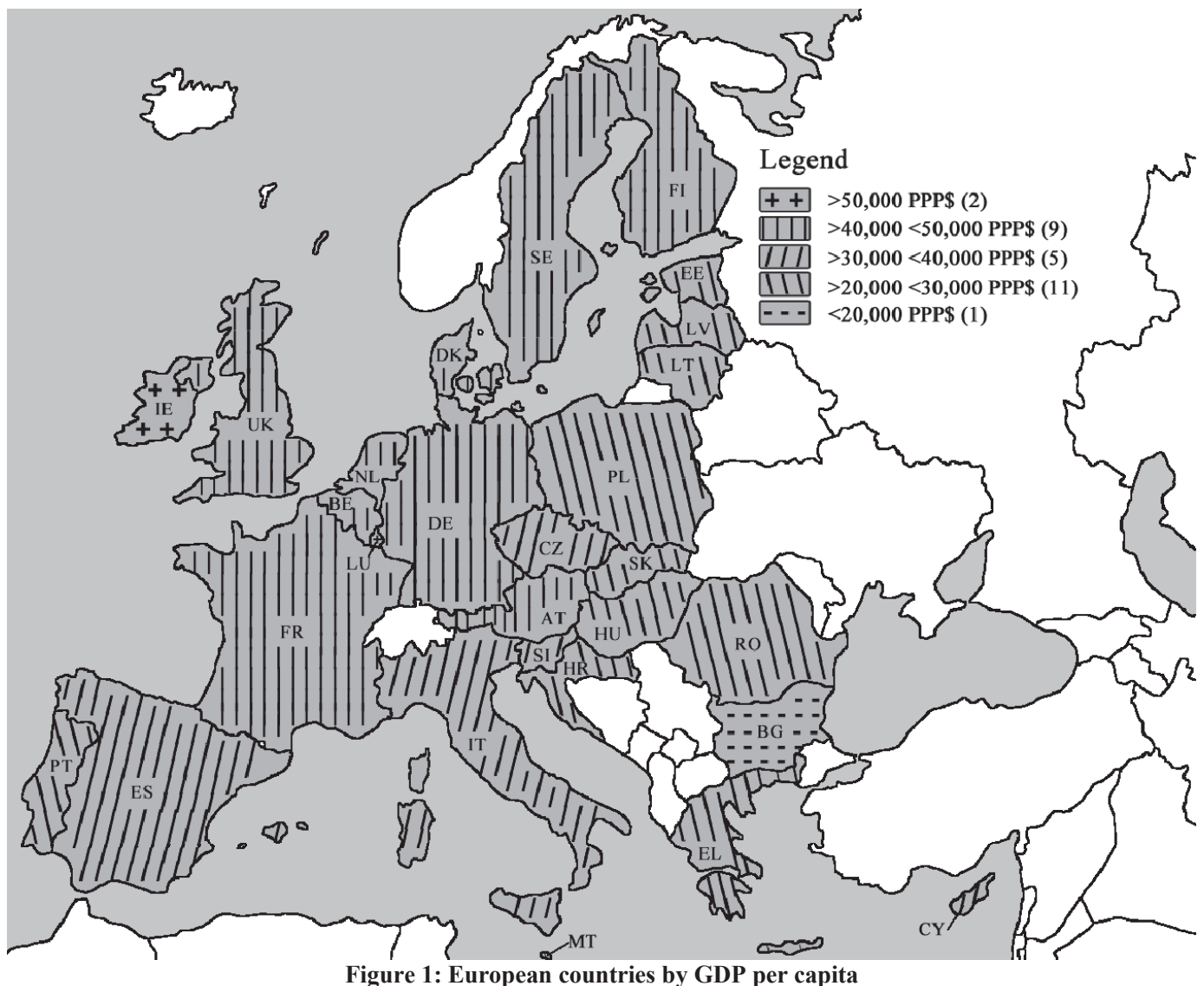

On the map above, we can see all twenty-eight European countries by GDP per capita in PPP\$ mentioning that France, even though the value for it is 39,678 PPP\$, so below 40.000 PPP\$ (as on the legend), is has been placed on the upper interval due to the prognoses made by statisticians from UNESCO.

What it is easy to see is the fact that with one exception - Portugal, all of the countries with a value for GDP per capita situated below 30,000 PPP\$, are located in Eastern Europe, while all the others are located in Western and Northern part of Europe. An ample body of literature has explored the way in which certain features of an environment influence the sustainability of ICT investments, some taking into consideration the political, social, and economic aspects in such a way that the readers might believe that all of the European countries possesses similar timeline in regard to the evolutions of their democracies. Consequently, it is important for researchers to specify which contextual factors influence the digital divide degree found among the European countries, rather than aggregate data and general level. However, this article is not focusing on the causes for this segregation; we believe that economists and experts in social sciences are already having the answer for this - we only provide a map with the current situation.

Going further on with our research, we made a different map, this time showing the number of Internet users as percentage from the total number of inhabitants. 


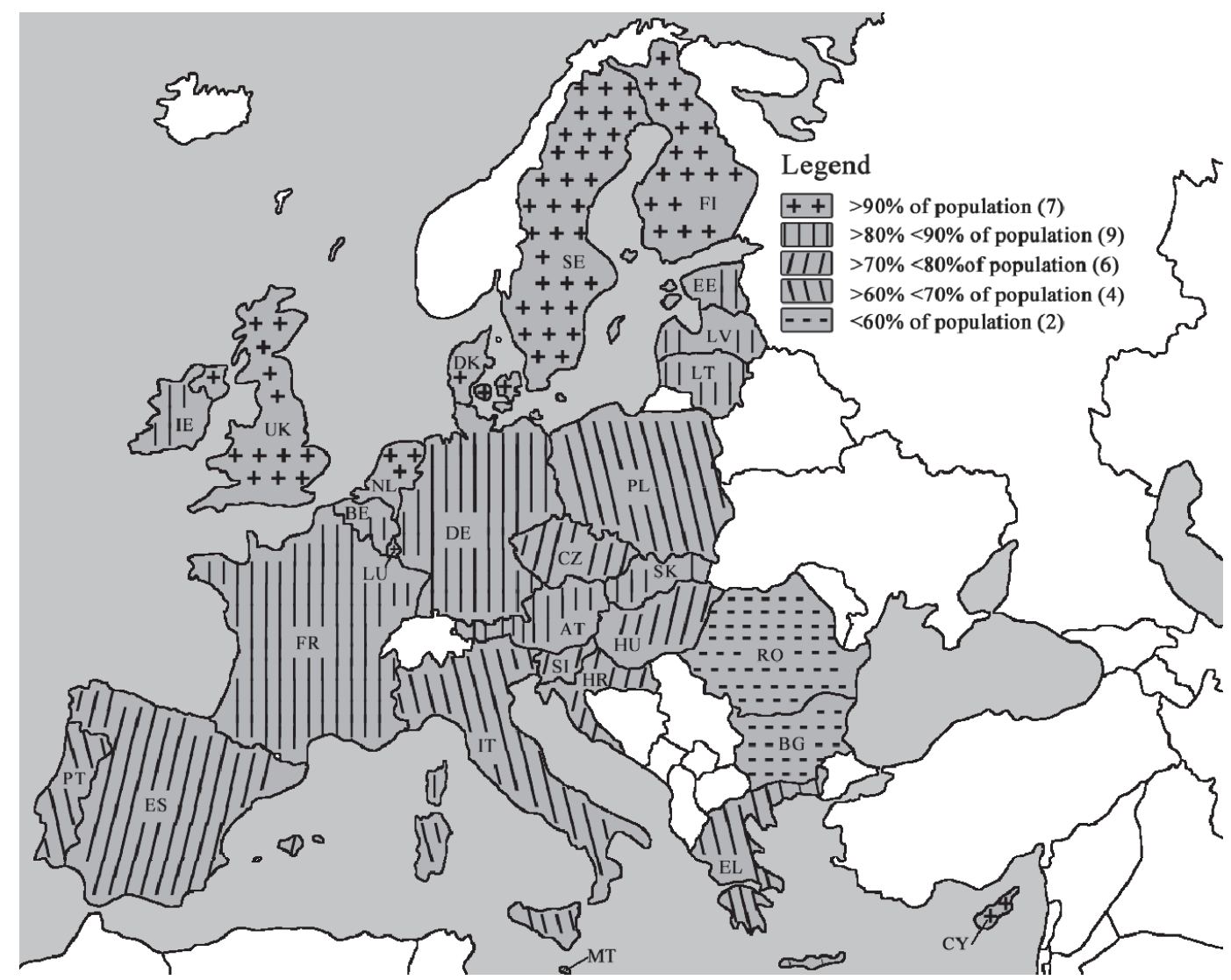

Figure 2: European countries by Internet users

Overlapping those two maps, we can see that twelve countries $(43 \%$ of the total number of European countries) are perfect match; those are Austria, Belgium, Bulgaria, Czech Republic, Finland, France, Germany, Luxembourg, Poland, Portugal, Slovenia and Spain. As previously demonstrated by the use of SPSS, there is a strong positive correlation in those two sets of data as well - Pearson correlation coefficient, $r$, being 0.584 between GDP per capita and the number of Internet users as percentage from the total number of inhabitants.

The data specified in the last column of the Table 1. - presenting the connection speed for the Internet users (broadband) shows, with very few exceptions, that high Internet speed connection is available all over Europe no matter the GDP or any other indicators we took into consideration for this study.

While correlating the expenditure for education as well as expenditure in Research and Development in the area of Engineering \& Technology with the number of Internet users, we found that $r$ is 0,530 in the first case - showing a medium positive correlation, and -0.432 in the second case - medium negative correlation. That means education must come first. Even though the country is investing in expensive IT solution for people, if they are not prepared to face the technology, the projects fail in achieving their goals. 


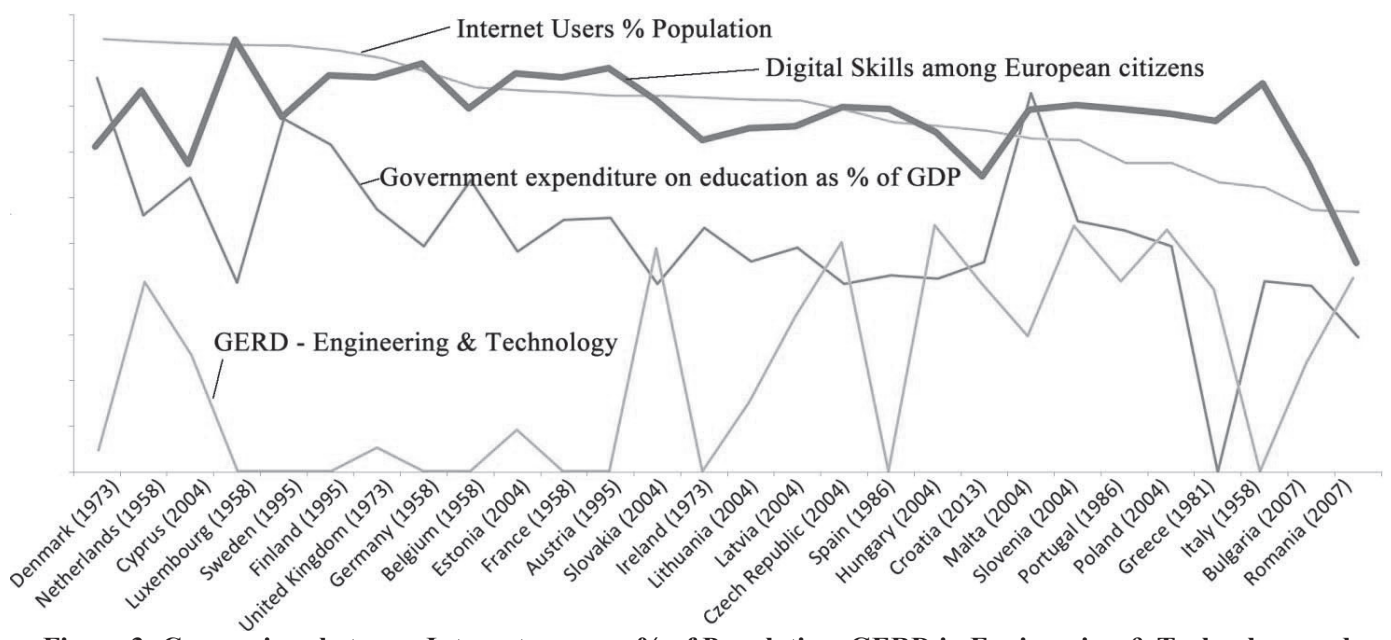

Figure 3: Comparison between Internet users as \% of Population, GERD in Engineering \& Technology and Government expenditure on education as \% of GDP and Digital skills among European citizens

We have to mention here that ten countries did not provide any data about GERD - Engineering \& Technology chapter for UNESCO Institute for Statistics; therefore this correlation might not be very accurate.

On the following map (Figure 4.); we present Europe seen by the number of users with basic digital skills [14]. As we can see from it as well as from the chart presented on the Figure 3., the correlation between the number of Internet users (Figure 2.) and Digital Skills among the European citizens (Figure 4.) is very weak ( $r$ being equal to 0.064). That proves the fact that Internet users are not necessary prepared for a proper use of ICT. Therefore, we believe that policymakers should be grounded in today's reality, because they are indeed, the only one who can bring about change nowadays it looks that there are some issues with the resource alignment to the policies intentions. For example, if we are to speak about Romania, even though it has a fast Internet connection [15], it is still lacking on other criteria such as Internet users and Digital skills, as we saw from the present study. 


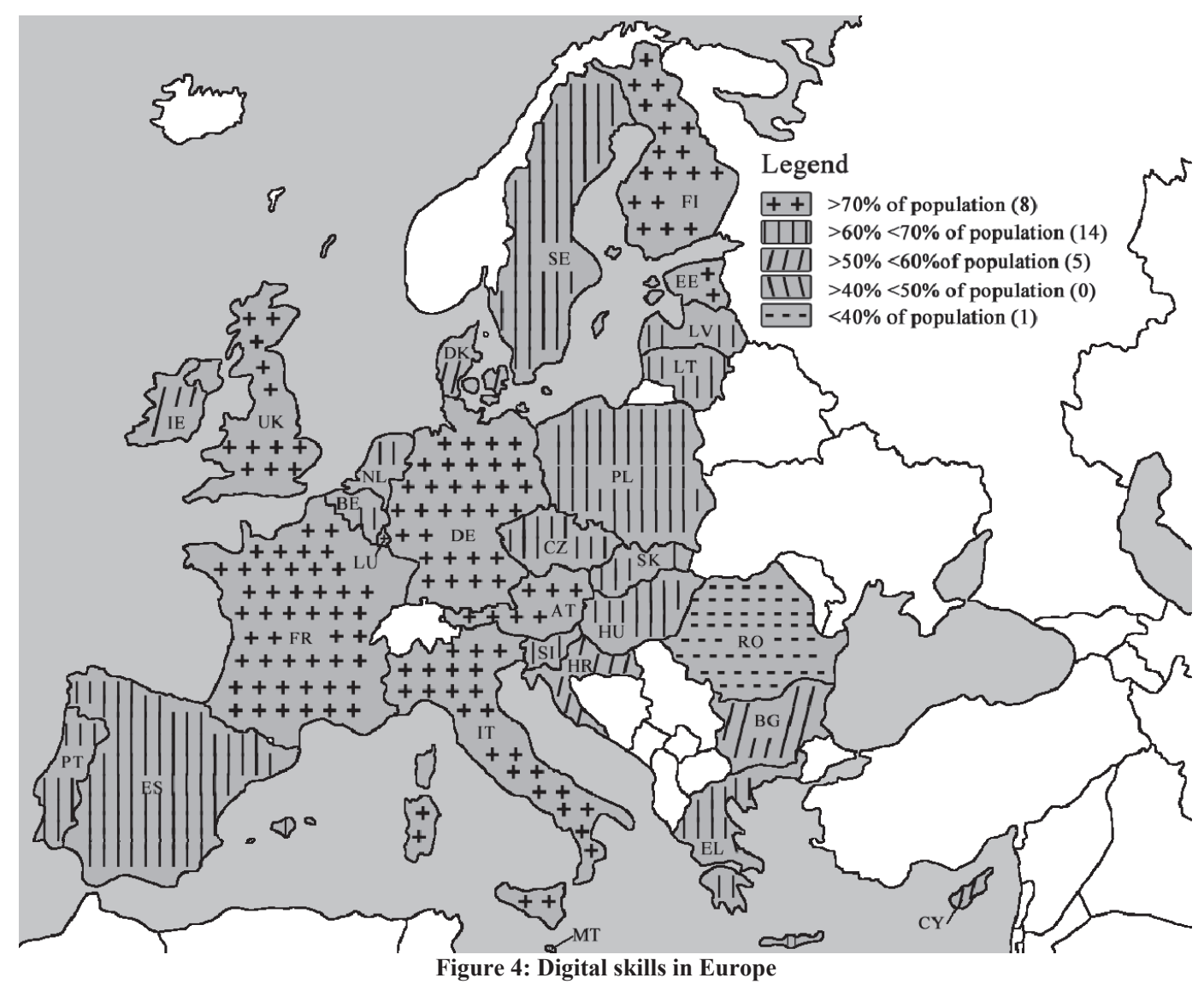

\section{Conclusions and discussions}

This research has attempted to provide a view over the European countries for a better understanding of differences among them regarding the ICT sector development as well as, to briefly present some of the conditions toward the viability related policies. At present, literature related to this subject, treated the differences among countries only by looking at the differences in figures and not paying attention to some contextual factor (both external and internal), thereby researchers should focus more upon them then looking on the numbers only.

Following ECDL, in the paper Perception and Reality: Measuring Digital Skills in Europe (the study assesses Digital skills and e-literacy in Austria, Denmark, Finland, Germany and Switzerland) we found that people routinely overestimate their abilities [16]. We tend to think that, in Romania at least, policymakers are overestimating citizens as well, and by doing that they don't put too much effort in increasing the level of ICT skills among them.

Some researcher noted that adoption of ICT within a given context is usually seen as contingent upon the prevalence factors related to infrastructure, literacy, income, and perceived needs [17].

ICT Policies and strategies can also fail due to reasons like: 
- $\quad$ They are viewed as populist gesture for increasing the political capital [18];

- $\quad$ People from the both sides resist changes that might be seen as imposed [19], [20];

- Unbalanced approaches (e. g. focus on project itself instead of its goals)

- $\quad$ Lack of competences among instructors;

- Unbalanced situations between the resource alignment on one hand and policies on the other [21].

The authors of this study agree that lacks of resources, political interference, and poor policy design or implementation are important reasons of failure for ICT policies - along with, of course, consistency and long term perspectives. That should be taken into consideration on further researches.

Taking into consideration the Romanian case, planning and implementing of the ITC policies are spread across various internal actors - therefore having a single coherent vision is difficult, not to mention that this might bring a lack of consistency as well. The involvement of the European Union, who's serving as a source of pressure, makes it even more complicated because the Romanian officials are focusing more on the projects goals and implementation instead on focusing on the social needs. Given the widespread calls for reducing the digital divide applications, researches addressing successful and less successful applications are needed - in order not to repeat the mistakes made already in the past.

According to the data we took into consideration for this research, only two countries matches perfectly on all the three maps - Belgium and Luxembourg, both of them being very high rated. We might think that only they were consistent in their approach (or it was just by accident - we did not study the political context over years neither in those two countries or anywhere else). However, the correlation we've made should be seen, understood and should be taking into consideration by the policymakers all over Europe. Through such a comparison, it is possible to show differences and similarities between the countries and how these contribute toward to the successful adoption of digital divide applications within the nations.

Beyond the differences, the internal digital-divide on some countries increases rapidly due to the quick adoption of ICT in urban centres versus rural areas. Taking that into consideration, ICT in education should be seen from two perspectives: the first reflects the role of it in providing support to people that cannot access the infrastructure while the other one is regarding the e-learning environment. By the last one, both teachers and the learning process itself is evolving rapidly encouraging collaboration and sharing knowledge.

The findings resulting from such a comparison are fairly intuitive, implying that they should also be easily generalizable to all e-government applications throughout various contexts, ranging from wealth advanced nations to those with fewer resources. 
Further research will bring into the analysis other instruments like ICT in education, e-government, the price for Internet connection and so on, attempting to see if there is any correlation between some indicators already used and those we have just mention.

\section{References}

[1] TAPSCOTT, D.: Growing Up Digital: The Rise of the Net Generation, McGraw-Hill, 1999.

[2] CARR, N.: The Shallows: What the Internet Is Doing to Our Brains, W. W. Norton, 2010.

[3] BALTAC, V.: Mituri si realitate in lumea digitala [Myths and Realities in the Digital World], Excel XXI Books, 2016.

[4] CLARK, R. E.: Media will never influence learning, Educational Technology Research and Development, 42(2) 1994, pp. 21-29.

[5] CEPIS - Council of European Professional Informatics Societies official Web portal http://www.cepis.org/ (accessed December 2016).

[6] ECDL Foundation official Web portal http://ecdl.org/about (accessed December 2016).

[7] KRUMOVA, M.: Open Data Benchmarking for Higher Education: Management and Technology Perspectives. Smart Cities Conference in Bucharest December 2016. http://administratiepublica.eu/smartcitiesconference/2016/program.htm

[8] EUROSTAT official Web portal http://ec.europa.eu/eurostat (accessed December 2016).

[9] HÎNCU, D., FRĂŁILĂ, L. and TANȚĂU, A.: Gap indicator for measuring digital divide, Management Research and Practice Vol. 3 Issue 2, 2011, pp 74-88.

[10] HRUSTEK, N. Ž., PROSSER, A. and DUŠAK, V.: A Multidimensional Model of EInclusion and its Implications, CEE e|Dem and e|Gov Days 2016, Austrian Computer Society, 2016.

[11] MÄNNEL, B.: European eGovernment for a Better Democracy, CEE e|Dem and e|Gov Days 2016, Austrian Computer Society, 2016.

[12] HIGHWAYMAPS.EU official Web portal http://www.highwaymaps.eu/, (accessed December 2016)

[13] EUROSTAT official Web portal Practising physicians, 2009 and 2014 (per 100000 inhabitants) http://ec.europa.eu/eurostat (accessed December 2016),

[14] EUROPEAN COMMISSION official Web portal, Digital Skills and Jobs Coalition, https://ec.europa.eu/digital-single-market/en/digital-skills-jobs-coalition (accessed December 2016)

[15] ROMANIA-INSIDER.COM media channel: US Presidential candidate Bernie Sanders: Bucharest residents have much faster Internet than most of the US, 2016, 
http://www.romania-insider.com/us-presidential-candidate-bernie-sanders-bucharestresidents-have-access-to-much-faster-internet-than-most-of-the-us/166176/

[16] ECDL: Perception and Reality: Measuring Digital Skills in Europe, 2016http://ecdl.org/media/perceptionandreality-measuringdigitalskillsineuropeecdlfoundationpositionpaper1.pdf

[17] ZANELLO, G. and MAASSEN, P. : Strengthening Citizen Agency and Accountability Through ICT, 2011, Public Management Review, 13(3), 363-382.

[18] SWYNGEDOUW, E.: Apocalypse Forever? Post-Political Populism and the Spectre of Climate Change, Theory Culture \& Society 27(2-3), 2010, pp 213-232.

[19] TYACK, D. and CUBAN, L.: Tinkering toward Utopia. Cambridge: Harvard University Press, 1995.

[20] TORBEN, R.: Change is not the problem - resistance to change is the problem, Change Management by Meliorate, 2013, https://www.torbenrick.eu/blog/change-management/ change-is-not-the-problem-resistance-to-change-is-the-problem/

[21] BULL, J.W., JOBSTVOGT, N., BÖHNKE-HENRICHS, A., MASCARENHAS, A., SITAS, N., BAULCOMB, C., LAMBINI, C.K., RAWLINS, M., BARAL, H., ZÄHRINGER, J., CARTER-SILK, E., BALZAN, M.V., KENTER, J.O., HÄYHÄ, T., PETZ, K. and KOSS, R.: Strengths, Weaknesses, Opportunities and Threats: A SWOT analysis of the ecosystem services framework. Ecosystem Services Volume 17, pp. 99-111. 